\title{
A New Species of Ludia (Salicaceae) from Madagascar's Eastern Littoral Forest
}

\author{
Zachary S. Rogers, Armand Randrianasolo, and James S. Miller
}

Missouri Botanical Garden, P.O. Box 299, St. Louis, Missouri 63166-0299, U.S.A.

zachary.rogers@mobot.org; armand.randrianasolo@mobot.org; james.miller@mobot.org

Abstract. Recent collecting efforts in Madagascar's eastern littoral forest have yielded a new species, Ludia craggiana Z. S. Rogers, Randrianasolo \& J. S. Miller (Salicaceae), which is apparently endemic to two sandy forest fragments located near Vohémar in northeastern Madagascar. This species is most similar to L. ludiifolia (H. Perrier) Capuron \& Sleumer, but can be distinguished by its more robust young stems and spines, glabrous or rarely puberulent twigs, petioles, midribs, and pedicels, coriaceous leaves with midveins and secondary venation of similar thickness, 50 to 60 stamens with emarginate anther connectives, and by the minutely granular-papillose fruit surface. Ludia craggiana is illustrated and assigned a provisional conservation status of endangered.

RÉsumé. Des inventaires botaniques récents effectués dans les forêts littorales de l'Est de Madagascar ont conduit à la découverte d'une nouvelle espèce Ludia craggiana Z. S. Rogers, Randrianasolo \& J. S. Miller (Salicaceae), qui est apparemment endémique de deux fragments de forêt littorale sur sable aux environs de Vohémar au NE de Madagascar. Cette espèce ressemble beaucoup à L. ludiifolia (H. Perrier) Capuron \& Sleumer mais se distingue de celle-ci par ses jeunes rameaux et ses épines plus robustes, ses ramilles et ses nervures médianes ainsi que ses pedicelles glabres ou rarement puberulents, ses feuilles coriaces à nervures primaires et secondaires d'épaisseur semblable, ses 50 à 60 élamines avec des anthères à connectifs emarginés, et par la surface du fruit finement granulaire-papillée. Une illustration ainsi qu'un statut de conservation provisoire rattaché à la catégorie "en danger" de cette espèce sont présentés.

Key words: IUCN Conservation Status, Ludia, Madagascar, Salicaceae.

Ludia Commerson ex Jussieu (Salicaceae) is composed of 23 species, 21 endemic to Madagascar. one endemic to the Comoros, and one widespread (L. mauritiana J. F. Gmelin) from eastern Africa to Madagascar, the Mascarenes, and the Seychelles
(Sleumer, 1972a, b; Schatz, 2001). The genus has traditionally been considered a member of Flacourtiaceae (Perrier de la Bâthie, 1946; Sleumer, 1972a), but Chase et al. (2002) showed that the family was polyphyletic and provided molecular data supporting a more broadly defined Salicaceae, including many genera from the Flacourtiaceae, with the remainder assigned to the Achariaceae. In their classification, Ludia was placed in the tribe Flacourtieae in this redefined Salicaceae. Within Madagascar, Ludia may be distinguished from Scolopia Schreber by its apetalous (vs. petalous) flowers, an anther connective that does not extend beyond the apex of the thecae (vs. distinctly elongated), and leaves that are almost always penninerved (vs. 3- to 5-palmatinerved) (Perrier de la Bâthie, 1946; Sleumer, 1972a, b; Schatz, 2001).

Since November 2000, three collections that represent an undescribed species of Ludia have been discovered through the Missouri Botanical Garden's efforts to inventory the fragmented eastern littoral forests of Madagascar. The species, L. craggiana Z. S. Rogers, Randrianasolo \& J. S. Miller, is formally described here and compared to L. ludiifolia (H. Perrier) Capuron \& Sleumer, the closest putative relative.

Ludia craggiana Z. S. Rogers, Randrianasolo \& J. S. Miller, sp. nov. TYPE: Madagascar. Antsiranana: "Fivondronona Vohémar, Firaisana Nosibe, Fokontany Anjiabe, forêt littorale sur sable d'Anaborano, près du Lac Sahaka," 25 m, 2 Nov. 2002, J. Rabenantoandro, R. Rabevohitra. G. McPherson, H. Ranarivelo, Jean Claude \& $M$. Sola 1085 (holotype, MO; isotypes, P, TEF). Figure 1.

Ludia craggiana; a L. ludiifolia caulibus juvenilibus et spinis robustioribus, ramunculis glabris vel raro puberulis (non dense pubescentibus), petiolis costis pedicellis trichomatibus rectis (non crispis) instructis, foliis coriaceis (non chartaceis) costis et nervis pariter prominentibus, staminibus 50 ad 60 (non 80 ad 90) antheris connectivo emarginato (non apiculato), fructibus minute granular-papillosis (non laevibus vel raro parum granular-papillosis) differt. 

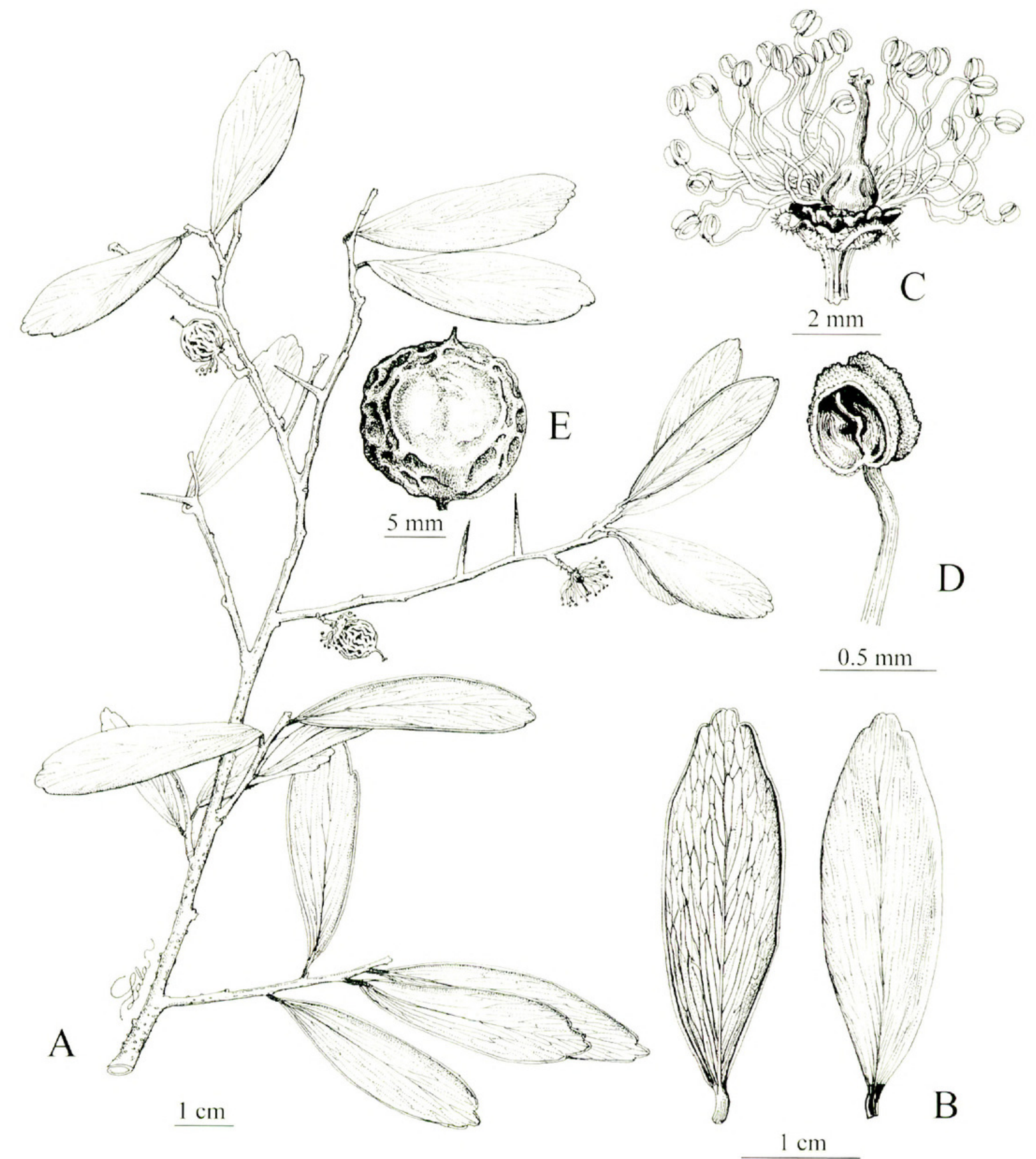

Figure 1. Ludia craggiana Z. S. Rogers, Randrianasolo \& J. S. Miller. - A. Habit. - B. Leaf (left, abaxial surface; right, adaxial surface). — C. Flower (about half of the stamens removed to simplify the illustration). - D. Stamen. - E. Fruit. A, C-D drawn from TEF isolype (J. Rabenantoandro et al. 1085). B \& E drawn from TEF paralype (R. Rabevohitra et al. $4500)$.

Trees to $10 \mathrm{~m}$ tall; young stems robust (ca. $1 \mathrm{~mm}$ diam.), glabrescent or rarely puberulent, densely lenticellate, spiny; spines axillary, lenticellate, (6-) 8-12 mm long, 1-1.5 mm wide (at base), rigid. Leaves alternate, stipulate; stipules small, caducous; petioles 1-2 mm long, glabrous or glabrescent; leaf blades obovate to oblanceolate, $2.1-5.1 \times 0.6-1.8(-2.3) \mathrm{cm}$, (1.5)2.2-4.6:1 length/width ratio, the apex with 3 to 6 crenate or sinuate teeth, those forming usually irregular shallow to deep sinuses, the base cuneate, the margins slightly revolute, coriaceous and rigid, the midrib glabrous or glabrescent, not or only slightly distinguishable from secondary veins, venation penninerved, strongly ascending, composed of many fine subparallel, slightly raised striate veins on both surfaces, tertiary and higher order venation reticulate, nearly as prominent as secondaries. Flowers solitary in the leaf axils, hermaphroditic, 
regular, pedicellate, subtended at base by 4 to 7 ovate bracts, these ca. $0.3 \mathrm{~mm}$ long, puberulous at apex; pedicels $1-1.5 \mathrm{~mm}$ long, puberulent to glabrescent; sepals 5 or 6 , lobed, imbricate, coriaceous, ciliate; petals absent; nectary disk annular, glabrous, composed of many fleshy fused segments, those unequally lobed at the apex; stamens ca. 50 to 60, persistent, inserted on a flattened receptacle; filaments 3$4.5 \mathrm{~mm}$ long, unequal, glabrous; anthers longitudinally dehiscent, orbicular, $0.4-0.5 \mathrm{~mm}$ long, the connective not extended (i.e., not apiculate), many filamentous trichomes intermingled between nectary disk and stamens; gynoecium ca. $2.5 \mathrm{~mm}$ long, glabrous; ovary superior, 1-locular, ovoid, ca. $1 \mathrm{~mm}$ long; style ca. $1.5 \mathrm{~mm}$ long, flattened, occasionally shortly 3-branched near apex; stigma lobed. Fruit bacciform, indehiscent, 2-seeded, globose, 1.3$1.6 \times$ ca. $1.4 \mathrm{~cm}$, glabrous; dried fruit wall wrinkled, minutely granular-papillose, ca. $0.3 \mathrm{~mm}$ thick, crustaceous; style persistent; seeds $9-10 \mathrm{~mm}$ long, hemispheroidal (rounded on one side, flattened on the side adpressed to adjacent seed); seed coat very hard; endosperm present.

Distribution and phenology. Ludia craggiana grows in two littoral forest fragments on sand (25$65 \mathrm{~m}$ elevation recorded on specimen labels), which are adjacent to the coastal city of Vohémar (northeastern Madagascar, Antsiranana Province). The species flowers in October and November and fruits from November through February.

Vernacular name. Lamoty ala (Rabenantoandro et al. 1085).

Etymology. Ludia craggiana is named in honor of Gordon M. Cragg, former Chief of the Natural Products Branch of the Developmental Therapeutics Program of the National Cancer Institute (NCI). The natural products program of the NCI has supported significant collection of plant samples from tropical Africa and Madagascar, for discovery and development of new anticancer drugs through a series of collecting contracts with the Missouri Botanical Garden since 1986 (see Miller \& Gereau, 2000; Miller et al., 2005). Dr. Cragg has been an enthusiastic supporter of botanical research and an outspoken advocate for conservation of tropical forests, recognizing them as a source of novel chemicals that provide a basis for drug development. Gordon Cragg's passion and enthusiastic support for botanical exploration is hereby acknowledged.

Conservation status (following IUCN, 2001, criteria). Ludia craggiana is known from two unprotected localities (ca. $30 \mathrm{~km}$ apart), which are part of the highly fragmented and severely threatened littoral forest vegetation remaining along the east coast of Madagascar. The estimated area of occupancy (AOO) for the species is $200 \mathrm{~km}^{2}$ based on a $10 \mathrm{~km}^{2}$ grid cell (size chosen based on the narrow distribution of the species and fragmented habitat of littoral vegetation in the region). An accurate extent of occurrence (EOO) is not calculable, given the lack of sufficient distribution points, but that figure is certainly much lower than the less than $5000 \mathrm{~km}^{2}$ minimum threshold of the Endangered category (i.e., criterion Bl). Ludia craggiana is assigned a provisional IUCN conservation status of Endangered (EN Blab + B2ab).

Ludia craggiana differs from $L$. ludiifolia by the more robust young stems and spines, glabrous or rarely puberulent (vs. densely pubescent) twigs, petioles, midribs, and pedicels that, when pubescent, are covered by straight (vs. curled) trichomes, coriaceous (vs. chartaceous) leaves with equally prominent (vs. more obvious) midveins compared to the secondary venation, 50 to 60 (vs. 80 to 90) stamens with emarginate (vs. apiculate) anther connectives, and by the minutely granular-papillose (vs. smooth, or rarely slightly papillose) fruit surface. In addition to these substantial morphological differences, the two species are geographically and ecologically distinct; L. craggiana grows in eastern coastal forest on sand, whereas $L$. ludiifolia grows much farther inland in the northwest of the island on lateritic soils.

Paratypes. MADAGASCAR. Antsiranana: "Vohémar, commune rurale Nosy be, forêt sublittorale d'Analabe, sur sables blancs," $R$. Rabevohitra, J. Rabenantoandro \& R. Razakamalala 4500 (MO, P, TEF); "Fivondronona Vohémar, commune Vohémar, localité Ranotsara, fourré de dune sableux littorales, à $5 \mathrm{~km}$ Sud de Vohémar," R. Randrianaivo, F. Rakotonasolo, H. Razafindraibe, A. Ratodimanana \& E. Rakotobe 597 (MO, P, TEF).

Acknowledgments. The authors kindly thank Roger Lala Andriamiarisoa for the illustration, Gordon McPherson for translating the diagnosis into Latin, Marina Rabarimanarivo for locating specimens in Madagascar, P. P. Lowry for his comments on the French abstract, and the curators of P, TAN, and TEF for allowing us to study the specimens deposited in their respective herbaria.

\section{Literature Cited}

Chase, M. W., S. Zmarzty, M. D. Lledo, K. J. Wurdack, S. M. Swensen \& M. F. Fay. 2002. When in doubt, put it in Flacourtiaceae: A molecular phylogenetic analysis based on plastid $r b c \mathrm{~L}$ DNA sequences. Kew Bull. 57: 141-181. IUCN. 2001. IUCN Red List Categories and Criteria: Version 3.1. IUCN, Gland, Switzerland, and Cambridge, United Kingdom. IUCN Species Survival Commission. 
Miller, J. S. \& R. E. Gereau. 2000. Therapeutic potential of plant-derived compounds: Realizing the potential. Pp. 25-37 in S. J. Cutler \& H. G. Cutler (editors), Biologically Active Natural Products: Pharmaceuticals. CRC Press, Boca Raton.

A. Bradley, A. Randrianasolo, R. Randrianaivo \& S. Rakotonandrasana. 2005. Sampling a diverse flora for novel biochemicals: An analysis of NCI collections from Madagascar. Econ. Bot. 59: 221-230.
Perrier de la Bâthie, H. 1946. Flacourtiacées. In H. Humbert (editor). Flore de Madagascar el des Comores 140: I-131. Schatz, G. E. 2001. Generic Tree Flora of Madagascar. Cromwell Press, Royal Bolanic Cardens. Kew, and Missouri Botanical Garden.

Sleumer, H. 1972a. Révision du genre Ludia Comm. ex Juss. (Flacourtiacées). Adansonia, sér. 2, 12: 79-102. 1972b. A taxonomic revision of the genus Scolopia Schreb. (Flacourtiaceae). Blumea 20: 25-64. 

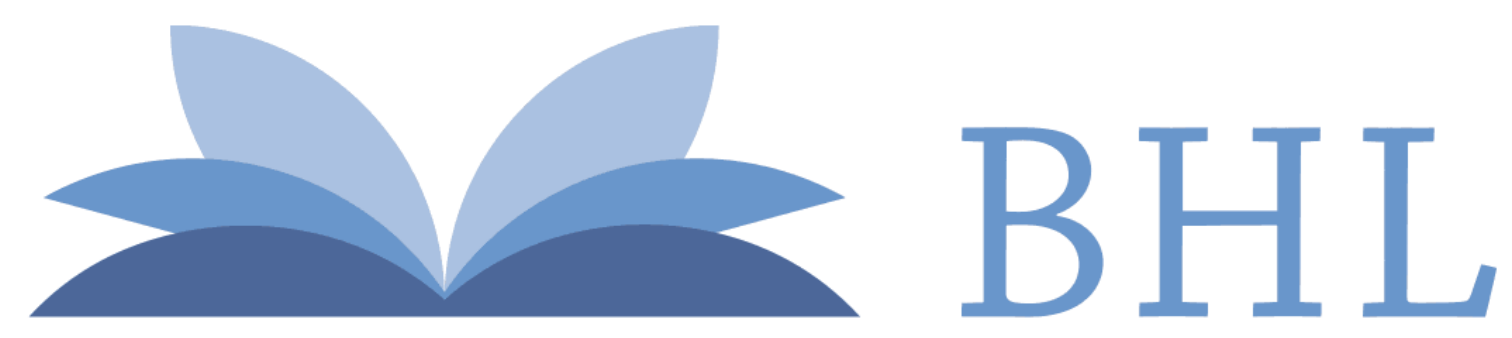

\section{Biodiversity Heritage Library}

Miller, James S., Randrianasolo, Armand, and Rogers, Zachary. 2006. "A new Species of Ludia (Salicaceae) from Madagascar's Eastern Littoral Forest." Novon a journal of botanical nomenclature from the Missouri Botanical Garden $16,409-412$.

View This Item Online: https://www.biodiversitylibrary.org/item/41804

Permalink: https://www.biodiversitylibrary.org/partpdf/37321

\section{Holding Institution}

Missouri Botanical Garden, Peter H. Raven Library

\section{Sponsored by}

Missouri Botanical Garden

\section{Copyright \& Reuse}

Copyright Status: In copyright. Digitized with the permission of the rights holder.

License: http://creativecommons.org/licenses/by-nc-sa/3.0/

Rights: https://biodiversitylibrary.org/permissions

This document was created from content at the Biodiversity Heritage Library, the world's largest open access digital library for biodiversity literature and archives. Visit BHL at https://www.biodiversitylibrary.org. 